\title{
PHENOTYPIC AND GENOTYPIC CHARACTERIZATION OF PSEUDOMONAS AERUGINOSA RECOVERED FROM KIDNEY LESIONS OF BROILER CHICKENS.
}

\author{
ISMAIL ABD EL-HAFEEZ RADWAN'; ABEER AHMED ELSAYED SHEHATA² and \\ SHAIMAA HASSAN ABD ELWAHAB ${ }^{2}$ \\ ${ }^{1}$ Bacteriology, Mycology and Immunology Department Faculty of Veterinary Medicine Beni-Suf University \\ ${ }^{2}$ Animal Health Research Institute El-Fayoum, Egypt.
}

Received: 27 December 2017; $\quad$ Accepted: 31 January 2018

\begin{abstract}
This work was planned to investigate the prevalence of $P$. aeruginosa in broiler chickens kidneys suffered from naked eye pathological lesions. Out of 240 examined kidneys samples, 25 isolates (10.4\%) of P. aeruginosa were recovered. Antimicrobial sensitivity pattern against 14 different antimicrobials comprising nine groups proved that isolates were resistant to most of the used antimicrobial agents. Phenotypic detection of extended spectrum beta-lactamases (ESBLs) producing isolates using modified double disk diffusion test revealed that, ten (40\%) were ESBLs producers. Genotypically using PCR, three ESBLs genes (TEM, Ctx-M and Shv) and three virulence genes (lasI, Tox $\mathrm{A}$ and $\mathrm{Plc} \mathrm{H}$ ) were detected with different percentages. Cinnamon and carvacrol oils were found bactericidal for $P$. aeruginosa at concentrations of $4 \%$ and $0.4 \%$ respectively.
\end{abstract}

Key words: P. aeruginosa, inflamed kidneys, ESBLS.

\section{INTRODUCTION}

Bacterial lesions in kidneys usually developed when bacteria enter the kidney following systemic disease through the renal arteries or the renal portal system or as a result of ascending infection (Schmidt et al., 2015). A wide range of bacteria has been reported to cause bacterial nephritis including Pseudomonas spp, (Al-Hiyali, 2005).

The environment of chickens house is ideal for growth of various microorganisms and thus serves as potential source of infection in chicken farms specially those organisms which are resistant to various antibiotic treatment. Pseudomonas aeruginosa considered as a good example of this environment associated infections (Kebede, 2010). Pseudomonas aeruginosa is a motile, Gram-negative, oxidase positive, non-spore forming rods with single arrangement or short chains (Elsayed et al., 2016). It producesa water soluble green pigment composed of fluorescentand pyocyanin with a specific fruity odor. P.aeruginosa considered being an opportunistic pathogen that can cause respiratory infections, septicemia and other forms when affecting birds (Fekadu, 2010). It affects newly hatched chickens drastically causing high mortality and mass death of

Corresponding author: Dr. Shaimaa Hassan Abd Elwahab E-mail address: tota.toto2021@yahoo.com

Present address: Animal Health Research Institute El-Fayoum, Egypt embryos (Dinev et al., 2013) resistance of $P$. aeruginosa to various antimicrobial agents is contribute to impermeability, multi-drug efflux, and a chromosomal AmpC $\beta$-lactamase. Noticeable resistance found among Amino-penicillins, third generation Cephalosporins, Monobactams, Carbapenems, aminoglycosides, and Fluoroquinolones. (Odusanya, 2002) and (Ogbulie et $a l .$, 2008) Outer membrane lipoprotein (OprL) implicated in efflux transport systems and affecting cell permeability (De Vos et al., 1997). Numerous virulence factors implicated in pathogenesis of $P$. aeruginosa as pyocyanin, pyoverdin, lipopolysaccharide, proteases, elastase, alkaline haemolysins, phospholipase $\mathrm{C}$, rhamnolipids, biofilm, Pilli, and flagella (Gupta et al., 2011). The complex type III secretion system recognized virulence determinant of $P$. aeruginosa capable of injecting proteins and secreted toxins into the host cell (Hauser 2009). Extended spectrum $\beta$-lactamases and AmpC $\beta$ lactamases are enzymes encoded by the chromosomal and plasmid genes of many bacteria including $p$. aeruginosa and have the ability to hydrolyze betalactam antibiotics leading to multiple antibiotic resistances (Black et al., 2005; Jacoby, 2009). Some p. aeruginosa found to be Co-producers of AmpC together with ESBL making the organisms nonsuceptible to $\beta$-lactam antibiotics including $\beta$-lactam and beta-lactam-inhibitor combinations (Feglo and Opoku 2014). Extended-spectrum $\beta$-lactamases (ESBLs) share the ability to hydrolyze thirdgeneration cephalosporins and aztreonam yet are inhibited by clavulanic acid. Typically, they derive 
from genes for CTX-M, TEM, or SHV, OXA, PER-1, VEB-1, BES-1, and Other ESBLs by mutations that alter the amino acid configuration around the active site of these $\beta$-lactamases. This extends the spectrum of $\beta$-lactam antibiotics susceptible to hydrolysis by these enzymes (Paterson and Bonomo, 2005).

\section{Aim of work:}

Characterization of $P$. aeruginosa recovered from kidney lesions of broiler chickens with special reference to ESBLs producing isolates and determination of the antibacterial effect of two selected essential oils namely: carvacrol and cinnamon oil on multi drug resistant isolates.

\section{MATERIALS AND METHODS}

\section{Samples}

Two hundred and forty kidney Samples of broiler chickens [Hubbard and Ross] 3-5 weeks from Elfayoum and Beni-suef governorates. These chickens were suffered from high mortalities respiratory manifestation with or without ruffled feathers and white or greenish white diarrhea was noticed in most of chickens. At P/M examination there was pericarditis in some chickens, air sacculitis in other, most of collected samples were from chickens have congested, pale and enlarged kidneys, also liver was enlarged and congested in many chickens. All samples were collected under complete aseptic conditions and cultivated on laboratory media according to (Quinn et al., 2002).

\section{Isolation and identification of $P$. aeruginosa \\ 2.1. Growth Media (Oxoid):}

Trypton soya broth and trypton soya agar, MacConkys agar and nutrient agar were used for recovery of $P$. aeruginosa from kidney tissues.

\subsection{Biochemical and biological testes:}

Pigment production, Oxidase test, Urease test, Indoltest, Citrate utilization test, Methyl red test, Voges-Proskauer test, Esculin hydrolysis, Gelatin liquefaction, Hemolysis on blood agar $(\beta)$, Growth at $4^{\circ} \mathrm{C}$ and $42^{\circ} \mathrm{C}$ and Fermentation tests all were done according to (Quinn et al., 2002).

\subsection{API 20 NE (bioMérieux, france):}

Furthermore, all $P$. aeruginosa isolates were then confirmed using API 20 NE (Bio-Meriux) according to producer instructions.

\section{Antimicrobial susceptibility test:}

The disk diffusion method was used to determine the susceptibility of $P$. aeruginosa isolates to several antibiotics of veterinary significance according to the standards and interpretative criteria described by
(CLSI, 2013). Fourteen different antibiotic disks (Oxoid) with the following concentrations were used: ampicillin $(10 \mu \mathrm{g})$, amoxicillin $(10 \mu \mathrm{g})$, amoxicillinclavulanic acid $(20 / 10 \mu \mathrm{g})$ cefotaxime $(30 \mu \mathrm{g})$ ceftriaxone $(30 \mu \mathrm{g})$, ceftazidime $(30 \mu \mathrm{g})$, aztreonam $(30 \mu \mathrm{g})$, Doxycycline $(30 \mu \mathrm{g})$, Lincomycin $(10 \mu \mathrm{g})$, Clindamycin $(2 \mu \mathrm{g})$, Fosfomycin $(200 \mu \mathrm{g})$, Florfenicol $(30 \mu \mathrm{g})$, colistinsulphate $(10 \mu \mathrm{g})$, and Apramycin $(30 \mu \mathrm{g})$, the results were recorded based on CLSI guidelines (CLSI, 213).

4. Detection of ESBL in $P$. aeruginosa using modified double disk diffusion (Kaur et al., 2013): Bacterial isolates of $P$. aeruginosa showed diameter of less than $27 \mathrm{~mm}$ for cefotaxime and less than $25 \mathrm{~mm}$ for ceftriaxone were tested to confirm the ESBLs production using the Modified Double Disc Synergy Test (MDDST).

Culture of the organisms was made on a MuellerHinton agar plate, as was recommended by (CLSI, 2013) then a disc of amoxicillin-clavulanate (20/10 $\mu \mathrm{g})$ was placed in the centre of the plate. Disks of cefotaxime, ceftazidime, aztreonam and ceftriaxone were placed with $20 \mathrm{~mm}$ apart center to center around amoxicillin-clavulanic disk and incubated at $37^{\circ} \mathrm{C}$ for $18 \mathrm{~h}$. ESBLs confirmed when any distortion or increase in the zone towards the disc of amoxicillinclavulanate was occurred.

\section{Molecular Identification}

5. 1.Extraction of DNA from $P$.aeruginosa isolates The bacteria were grown on $T S-Y E$ agar plates at $37^{\circ} \mathrm{C}$ and up to 100 colonies from the plates were combined. The DNA was obtained by suspending colonies of bacteria in $500 \mu \mathrm{l}$ of PBS, pH 7.2, then washing 3 times in PBS. The cell suspension was centrifuged for $10 \mathrm{~min}$ at $14,000 \mathrm{xg}$ the bacterial pellets were resuspended in $400 \mu 1$ Tris-EDTA buffer (pH 8.0) and DNA extracted by heat block method at $98{ }^{\circ} \mathrm{C}$ for $10 \mathrm{~min}$.

\subsection{Multiplex PCR for the detection of ESBL genes in P.aeruoginosa isolates}

The amplified reactions were performed in $50 \mathrm{ul}$ volumes in micro-amplification tubes (PCR tubes). The reaction mixture consisted of $10 \mu \mathrm{l}(200 \mathrm{ng})$ of extracted DNA template from bacterial cultures, $5 \mu \mathrm{l}$ 10X PCR buffer, $0.375 \mu 1 \mathrm{MgCl}_{2}(1.5 \mathrm{mM}), 1.25 \mu \mathrm{l}$ dNTPs $(250 \mu \mathrm{M}), 0.25 \mu \mathrm{l}(1.25$ Unit) Taq DNA polymerase, $0.25 \mu \mathrm{l}(0.5 \mu \mathrm{M})$ from each primer pairs and the volume of the reaction mixture was completed to $50 \mu \mathrm{l}$ using DDW.

PCR amplifications were performed with a thermal cycler adjusted as follows: 
Table 1: Cycling conditions of the different primers during PCR.

\begin{tabular}{ccccccc}
\hline & $\begin{array}{c}\text { Initial } \\
\text { Denaturation }\end{array}$ & $\begin{array}{c}\text { Secondary } \\
\text { Denaturation }\end{array}$ & Annealing & Extension & $\begin{array}{c}\text { No. of } \\
\text { amplification } \\
\text { cycles }\end{array}$ & $\begin{array}{c}\text { Final } \\
\text { extension }\end{array}$ \\
\hline Temperature & $95^{\circ} \mathrm{C}$ & $95^{\circ} \mathrm{C}$ & $55^{\circ} \mathrm{C}$ & $72^{\circ} \mathrm{C}$ & 30 & $72^{\circ} \mathrm{C}$ \\
\hline Time & $2 \mathrm{~min}$ & $40 \mathrm{sec}$ & $40 \mathrm{sec}$ & $2 \mathrm{~min}$ & $10 \mathrm{~min}$ \\
\hline
\end{tabular}

The PCR products were stored in the thermal cycler at $4^{\circ} \mathrm{C}$ until used.

5.3. Screening of PCR products by agarose gel electrophoresis:-

Two grams agarose was added to $100 \mathrm{ml}$ Tris Acetate EDTA (TAE) buffer. The agarose was autoclaved for 10 minutes and $0.5 \mu \mathrm{g} / \mathrm{ml}$ ethidium bromide was added and then left to cool to room temperature. The gel tray was tapped and the warm agarose was poured in. The comb was inserted in the agarose which was left to polymerize. After hardening, the tray was untapped, the comb was removed and the gel was applied to the electrophoresis cell. The cell was filled with TAE buffer. $10 \mu \mathrm{l}$ of each of the PCR product samples were applied to the gel along with $5 \mu$ l molecular weight marker after mixing each with $1 \mu 1$ loading buffer on a piece of parafilm. Each mixture was applied to a slot using $10 \mu \mathrm{l}$ micropipette. The electrophoresis cell was covered and the power supply was adjusted at $10 \mathrm{Volt} / \mathrm{cm}$. The gel was taken out from the cell and examined under short wave UV trans illuminator. The gel was photographed in order to obtain a permanent record using digital camera (Acer CR-5130, China).

Table 2: Oligonucleotide primers sequences and size of the PCR-targeted products PCR for P.aeruoginosa isolates (ESBL Genes and virulence Genes).

\begin{tabular}{|c|c|c|c|c|}
\hline Primer & & Sequence & Amplification product & Reference \\
\hline \multirow{2}{*}{ TEM } & $\mathrm{F}$ & 5- TCCGCTCATGAGACAATAACC-3 & \multirow{2}{*}{296 bp } & \multirow{6}{*}{$\begin{array}{c}\text { (Sturenburg } e \\
a l ., 2004)\end{array}$} \\
\hline & $\mathrm{R}$ & 5- ATAATACCGCACCACATAGCAG -3 & & \\
\hline \multirow{2}{*}{$C t x-M$} & $\mathrm{~F}$ & 5- TCTTCCAGAATAAGGAATCCC-3 & \multirow{2}{*}{909 bp } & \\
\hline & $\mathrm{R}$ & 5- CCGTTTCCGCTATTACAAAC-3 & & \\
\hline \multirow{2}{*}{ Shv } & $\mathrm{F}$ & 5- TACCATGAGCGATAACAGCG -3 & \multirow{2}{*}{$450 \mathrm{bp}$} & \\
\hline & $\mathrm{R}$ & 5-GATTTGCTGATTTCGCTCGG -3 & & \\
\hline \multirow{2}{*}{ lasI } & $\mathrm{F}$ & 5-CGTGCTCAAGTGTTCAAGG -3 & \multirow{2}{*}{ 295bp } & \multirow{6}{*}{$\begin{array}{c}\text { (Sabharwal } e t \\
\text { al., 2014) }\end{array}$} \\
\hline & $\mathrm{R}$ & 5-TACAGTCGGAAAAGCCCAG -3 & & \\
\hline \multirow{2}{*}{ Tox $A$} & $\mathrm{~F}$ & 5-GGAGCGCAACTATCCCACT -3 & \multirow{2}{*}{$150 \mathrm{bp}$} & \\
\hline & $\mathrm{R}$ & 5- TGGTAGCCGACGAACACATA -3 & & \\
\hline \multirow{2}{*}{ Plc H } & $\mathrm{F}$ & 5-GAAGCCATGGGCTACTTCAA -3 & \multirow{2}{*}{$307 \mathrm{bp}$} & \\
\hline & $\mathrm{R}$ & 5-AGAGTGACGAGGAGCGGTAG -3 & & \\
\hline
\end{tabular}

6. Detection of anti-bacterial effect of essential oils (cinnamon and carvacrol) on bacterial isolates using agar dilution method (Koneman et al., 1992):

All tested oils were sterilized by filtration with 0.45 $\mu \mathrm{m}$ pore diameter cellulose filter membrane and Tween 20 was added $(0.5 \% \mathrm{v} / \mathrm{v})$ to facilitate the emulsification of the oil.

The oils then mixed with TSA medium at concentrations $(0.5,1,2,4$ and $5 \%$ for cinnamon oil) and $(0.01,0.02,0.1$ and 0.4 for carvacrol oil) and poured in sterile petri dishes.

The standardized bacterial suspensions (adjusted to McFarland standard tube No. 0.5) were swabbed thoroughly on agar plates containing different concentrations of examined oils and incubated at $37^{\circ}$ and examined daily for bacterial growth up to three days.

\section{RESULTS}

1. Recovery rate of P.aeruginosa in bacteriologically examined kidney lesions:

Out of 240 bacteriologically screened pathologically affected kidneys, 25 isolates (10.4\%) of p.aeruginosa were recovered.

\section{Results of Antimicrobial sensitivity of examined} isolates: 
A strong resistance of $P$. aeruginosa to examined antimicrobials have been noticed, all isolates showed complete resistance (100\%) to Amoxicillin (AMX), Ampicillin (AMP), Clindamycin (DA) followed by amoxicillin-clavulanic acid (AMC) (96\%). While, resistance to Apramycin and Colistinsulphate (CT) were $92 \%$ for each and $84 \%$ for Doxycycline (DO), $80 \%$ for both Florfenicol (FFC) and Lincomycin (MY), 72\% for Fosfomycin (F+T). cephalosporins and Monobactam antibiotics Including Ceftriaxone (CRO) Cefotaxime (CTX) Ceftazidime (CAZ) and aztreonam (ATM) showed resistance of $64 \%, 60 \%$, $56 \%, 56 \%$ respectively.

\section{Results of phenotypic detection of ESBL} sprodusing isolates:

All 25 P. aeruginosa isolates under study showed either resistance or intermediate susceptibility pattern to one or more of the extended spectrum beta- lactamases were subjected to modified double disk diffusion test to confirm ESBLs production. ESBLs were confirmed phenotypically in $10(40 \%)$ out of 25 isolates of $P$. aeruginosa recovered from inflamed kidneys.

\section{Results of molecular characterization of} P.aeruginosa under study:

Concerning the molecular investigations of ESBLs gens namely (TEM, Ctx-M and Shv) two isolates which phenotypically proved to be ESBLS producer were found negative to the three intended gens. Meanwhile Ctx-M gene was the most prevalent gene with a percentage of $50 \%$ and five isolates harbored at least two different ESBLs gens. Regarding virulence gens eight out of ten tested isolates harbored one $(50 \%)$ or two $(50 \%)$ of the three intended gens. The most prevalent virulent gene was Plc H $(60 \%)$.

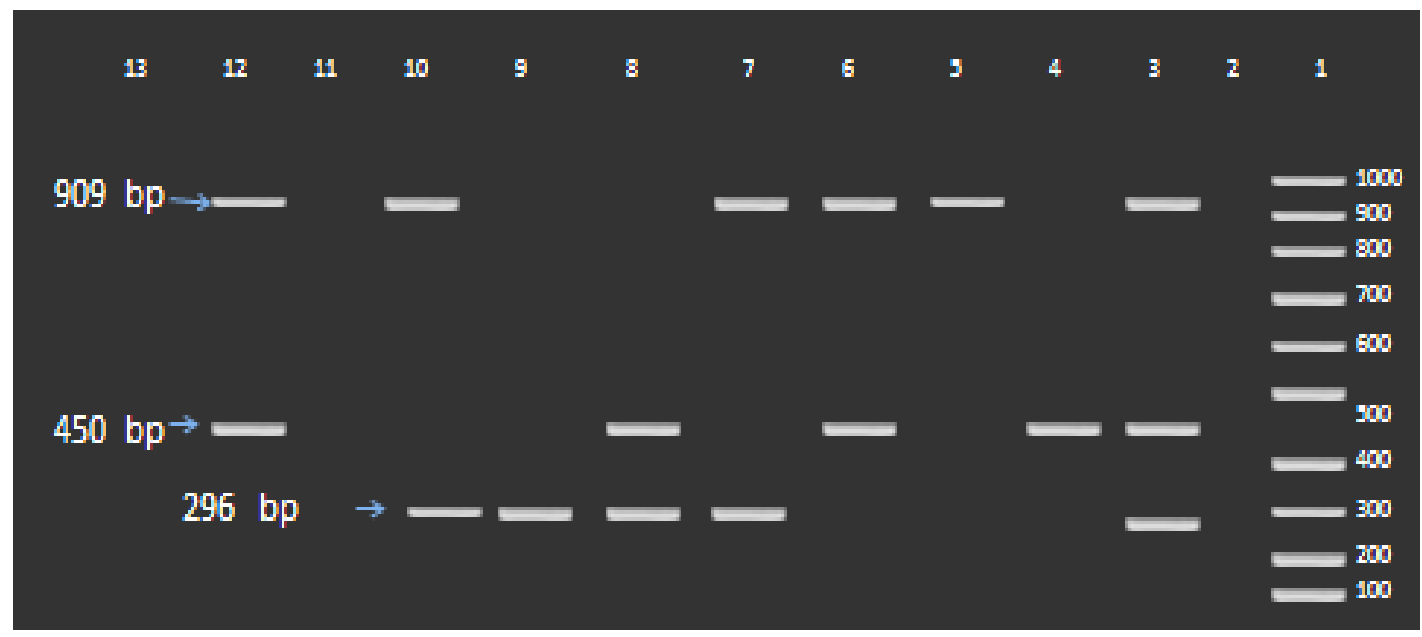

Fig. (1): Gel electrophoresis show positive amplification of P.aeruginosa isolates at 296, 909 and 450 bp of $T E M, C T X-M$ and $S H V$ respectively by using the specific primers.

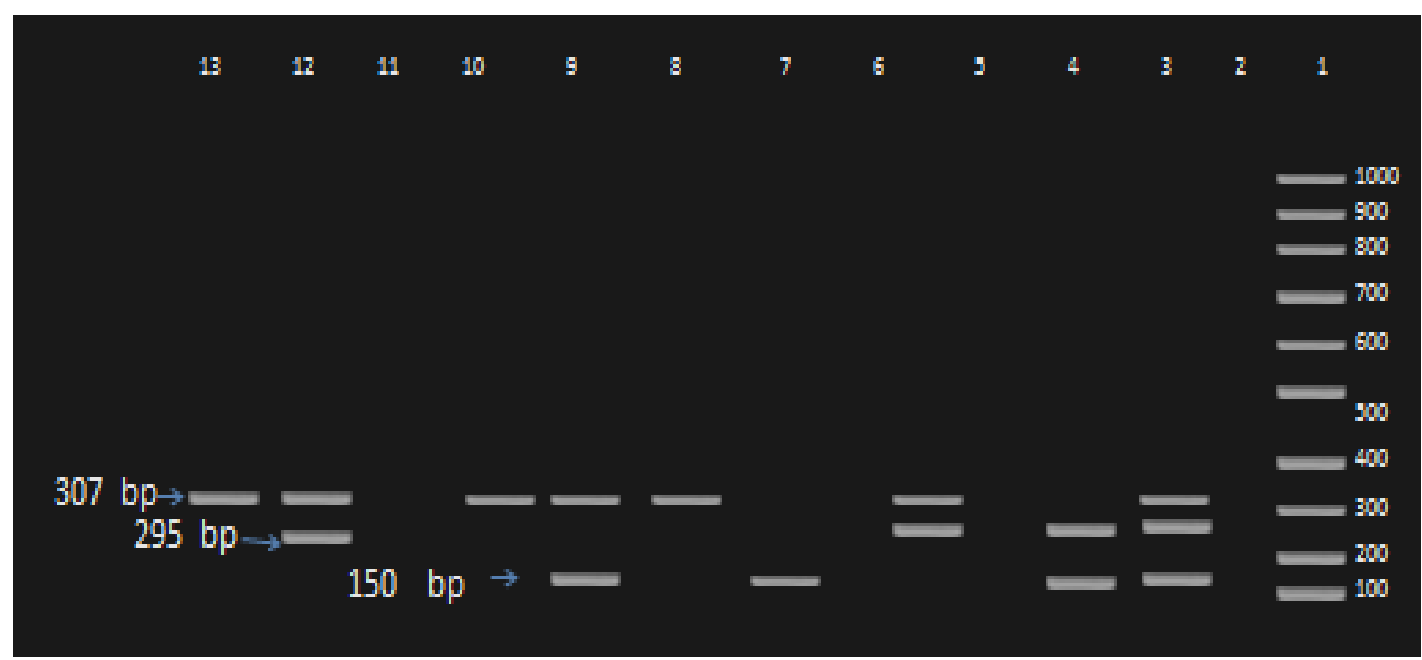

Fig. (2): Gel electrophoresis show positive amplification of $P$. aeruginosa isolates at 150, 295 and 307 bp of Tox A, lasI and Plc $H$ respectively by using the specific primers. 
Table 3: Results of molecular characterization of tested genes.

\begin{tabular}{|c|c|c|c|c|c|}
\hline & \multirow[t]{2}{*}{ Genes } & \multicolumn{2}{|c|}{ Positive } & \multicolumn{2}{|c|}{ Negative } \\
\hline \multirow{4}{*}{$\vec{\infty}$} & & No. & $\%$ & No. & $\%$ \\
\hline & $T E M$ & 4 & 40 & 6 & 60 \\
\hline & Ctx-M & 5 & 50 & 5 & 50 \\
\hline & Shv & 4 & 40 & 6 & 60 \\
\hline \multirow{3}{*}{ 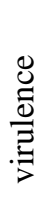 } & lasI & 3 & 30 & 7 & 70 \\
\hline & $\operatorname{Tox} A$ & 3 & 30 & 7 & 70 \\
\hline & Plc $\mathrm{H}$ & 6 & 60 & 4 & 40 \\
\hline
\end{tabular}

\section{No.: Number of isolates.}

$\%$ : was calculated according to the total number of the examined cases.

\section{Results of antibacterial effect of carvacrol and cinnamon oils in p.aeruginosa isolates:}

Two essential oils (cinnamon and carvacrol) were tested for their antimicrobial activity against the 25 p.aeruginosa isolates. Cinnamon oil completely inhibited the growth of all tested isolates at concentration of $4 \%$ while at concentration of $3 \%$ all p.aeruginosa isolates completely loss their ability to produce pigment and grown as white colonies. carvacrol oil exerted strong bactericidal effect against p.aeruginosa at concentration of $0.4 \%$ while at $0.2 \%$ concentration the isolates lost the ability for pigment production.

\section{DISCUSSION}

Pseudomonas aeruginosa is the one which can be cited as a good example of environment associated infection and may cause a serious problem in poultry farms. Generally, it is considered to be an opportunistic organism that produces septicemia and other disease forms when introduced into tissues of susceptible birds, $P$. aeruginosa can be highly virulent causing $50 \quad-100 \%$ mortality in experimentally infected 4-week-old chickens. (kebede, 2010). in this work, a total of 25 p.aeruginosa isolates out of 240 bacteriologically examined 240 inflamed kidneys were recovered with a percentage of (10.4\%). In chickens, $P$. aeruginosa produces dyspenia and cheesy deposits on the serous surfaces lining the air sacs and peritoneal cavity also congestion of internal organs, perihepatitis and pericarditis (Kheir El din et al., 1985). (Shukla and Mishra 2015) induced experimental infection in 7 day old chicks with p.aeruginosa intra muscularly and found that the liver, lung and kidneys were highly congested with necrotic foci on the liver and visceral organs. Results of Antimicrobial sensitivity of examined isolates revealed that all isolates of $P$. aeruginosa were highly resistant to Amoxicillin, Ampicillin, Clindamycin and amoxicillin-clavulanic acid followed by Apramycin and Colistinsulphate. The recorded resistance to Cephalosporins and
Monobactam antibiotics Including (Ceftriaxone, Cefotaxime, Ceftazidime, and aztreonam) were (64\%, $60 \%, 56 \%$ and 56\%) respectively. (Nikaido 1994 and Odusanya 2002), concluded that P.aeruginosa was resistant to various antimicrobial agents as $\alpha$-carboxyand Amino-penicillins, third and fourth-generation Cephalosporins, Monobactams, Fluoroquinolones, Carbapenems, and aminoglycosides might be due to up-regulation of efflux or down regulation of permeability also may due to hyper production of the chromosomal AmpC $\beta$-lactamase.

The cephalosporins had been developed in response to the increased prevalence of $\beta$-lactamases in certain organisms as E.coli and K.pneumoniae and the spread of these $\beta$-lactamases into new hosts.Using modified double disk diffusion test to confirm ESBLs production, ten $(40 \%)$ of the tested isolates were confirmed phenotypically to be ESBLs producers. The molecularly examined 10 phenotypically ESBLs producing isolates for (TEM, Ctx-M and Shv), 8 isolates only were found to harbored one or more of the investigated gens Ctx-M gene was the most prevalent gene with a percentage of $50 \%$ and five isolates harbored at least two different ESBLs gens. ESBLs derive from genes for TEM-1, TEM-2, or SHV-1 and others by mutations that alter the amino acid configuration around the active site of these $\beta$ lactamases.

This extends the spectrum of $\beta$-lactam antibiotics susceptible to hydrolysis by these enzymes (Paterson and Bonomo 2005). The ESBLs are frequently plasmid encoded. Plasmids responsible for ESBL production frequently carry genes encoding resistance to other drug classes. The virulence associated genes were lasI, Tox A and Plc $\mathrm{H}$ with the prevalence of $30 \%, 30 \%$ and $60 \%$ respectively. The Exotoxin A is produced by most of $P$. aeruginosa strains It can inhibit biosynthesis of eukaryotic protein at the level of polypeptide chain elongation (Khanand Cerniglia, 1994). 
Cinnamon oil completely inhibited the growth of p.aeruginosa isolates at concentration of $4 \%$ and inhibited the exo-pigments production at $3 \%$ concentration. On the other hand carvacrol oil exhibited bactericidal effect at concentration of $0.4 \%$ and inhibited the exo-pigment production at $0.2 \%$ concentration. Essential oils (EOs) and other extracts of plants have evoked interest owing to other potential uses as alternative remedies for the treatment of many infectious diseases. Some of these Eos show inhibitory effect against multidrug resistant bacteria. Essential oils with its anti-quorum sensing activity that might be important to reduce virulence and pathogenicity of drug resistant bacteria (olveira and cunha, 2008). Cinnamon and carvacrol are phenolic compounds with both hydrophobic and hydrophilic properties, interacts with the lipid bilayer of the bacterial cytoplasmic membrane causing loss of its integrity (zhu et al., 2016).

\section{REFERENCES}

Alan R. Hauser (2009): The Type III Secretion System of Pseudomonas aeruginosa: Infection by Injection. Nat. Rev. Microbiol. 7(9): 654665.

Al-Hiyali, H.M.; Al-Kabbi, H.T. and Abdulkarim, S. (2005): Isolation of four types of bacteria that cause kidney damage in broiler chickens. Iraqi J. Vet. Med., 29: 33-42.

Black, J.A.; Moland, E.S. and Thomson, K.S. (2005): AmpC disc test for detection of plasmidmediated AmpC beta-lactamases in Enterobacteriaceae lacking chromosomal AmpC- blactamases. J. Clin. Microbiol. 43: 3110-3113.

Clinical and Laboratory Standards Institute (CLSI, 2013): Performance standards for antimicrobial susceptibility testing; twentythird informational supplements. M100-S23; $1-61$.

De Vos, D.; Lim, A.J.; Pirnay, J.P.; Struelens, M.; Vandenvelde, $\quad$ C.; Duinslaeger, L.; Vanderkelen A. and Cornelis, P. (1997): Direct detection and identification of Pseudomonas aeruginosa in clinical samples such as skin biopsy specimens and expectorations by multiplex PCR based on two outermembrane lipoprotein genes, oprI and oprL. J. Clin. Microbiol., 35: 1295-1299.

Dinev, I.; Denev, S. and Beev, G. (2013): Clinical and morphological studies on spontaneous cases of Pseudomonas aeruginosa infections in birds. Pak. Vet. J. 33: 398-400.

Elsayed, M.S.A.; Ammar, A.M.; Al Shehri, Z.S.; AbdEl Rahman and Abd-El Rahman, N.A.(2016): Virulence Repertoire of Pseudomonas aeruginosa from some Poultry Farms with Detection of Resistance to Various Antimicrobials and Plant Extracts. Cellular and Molecular Biology; 62: 124.
Feglo, P. and Opoku, S. (2014): AmpC betalactamase production among Pseudomonas aeruginosa and Proteus mirabilis isolates at the Komfo Anokye Teaching Hospital, Kumasi, Ghana. Journal of Microbiology and Antimicrobials 6:13-20.

Gupta, R.K.; Setia, S. and Harjai, K. (2011): Expression of Quorum Sensing and Virulence Factors Are Interlinked in Pseudomonas aeruginosa: an in vitro Approach. American Journal of Biomedical Sciences: 1937-9080.

Hauser, A.R. (2009): The type III secretion system of Pseudomonas aeruginosa: infection by injection. Nat Rev Microbiol. 7(9):654-65.

Jacoby, G.A. (2009): AmpC $\beta$-Lactamases. Clin. Microbiol. Rev. 22(1):161-182.

Kaur, J.; Chopra, S.; Sheevani and Mahajan, G. (2013): Modified Double Disc Synergy Test to Detect ESBL Production in Urinary Isolates of Escherichia coli and Klebsiella pneumonia. J. Clin Diagn Res.; 7(2): 229-233.

Kebede, F. (2010): Pseudomonas infection in chickens. Journal of Veterinary Medicine and Animal Health Vol. 2(4), pp. 55-58.

Khan, A.A. and Cerniglia, C.E. (1994): Detection of Pseudomonas aeruginosa from clinical and environmental samples by amplification of the exotoxin A gene using PCR. Appl. Environ. Microbiol., 60: 3739-3745.

Kheir El-Din; A.W. and Awaad, M.H.H. (1985): Pseudomonas infection in turkeys. Vet. Med. J., 33 (2), 211-218.

Koneman, E.W.; Allen, S.D.; Janda, W.M.; Schrechknberger, P.C. and Winn, W.C. (1992): Colour atlas and textbook of diagnostic microbiology; $4^{\text {th }}$ Ed.; J.B. Lippencott company, Philadelphia.

Nikaido, H. (1994): Prevention of drug access to bacterial targets: permeability barriers and active efflux. Science. 264: 382-388.

Odusanya, M.D. (2002): Antibiotic susceptibility of microorganisms at a general hospital in Lagos Nigeria. J. Natl. Med. Assoc., 94: 994-998.

Ogbulie, J.N.; Adieze, I.E. and Nwankwo, N.C. (2008): Susceptibilty pattern of some clinical bacterial isolates to selected antibiotics and disinfectants. Polish J. Microbiol., 57: 199204.

Oliveira, A. and Cunha, M.L.R. (2008): Bacterial biofilms with emphasis on coagulase-negative staphylococci. J. Venom. Anim. Toxins incl. Trop. Dis. 14:572-596

Paterson, D.L. and Bonomo, R.A. (2005): ExtendedSpectrum $\beta$-Lactamases: a Clinical Update. Clin Microbiol Rev.; 18(4): 657-686.

Quinn, P.J.; Markey, B.K.; Carter, M.E.: Donnelly, W.J. and Leonard, F.C. (2002): Veterinary microbiology and microbial disease. Text book MPG books Ltd, com. well.

Sabharwal, N.; Dhall, S.; Chhibber, S. and Harjai, K. (2014): Molecular detection of virulence genes 
as markers in Pseudomonas aeruginosa isolated from urinary tract infections (p.v gens). Int. J. Mol. Epidemiol. Genet.; 5(3): 125-134.

Schmidt, R.E.; Reavill, D.R. and Phalen, D.N. (2015): Pathology of Pet and Aviary Birds, Second Edition. John Wiley and Sons, Inc.

Shukla, S. and Mishra, P. (2015): Pseudomonas aeruginosa Infection in Broiler Chicks in Jabalpur International Journal of Extensive Research 6:37-39.
Sturenburg, E.; Lang, M.; Horstkotte, M.A.; Laufs, R. and Mack, D. (2004): Evaluation of the Micro Scan ESBL plus confirmation panel for detection of extended-spectrum betalactamases in clinical isolates of oxyiminocephalosporin-resistant Gram-negative bacteria. The Journal of antimicrobial chemotherapy 54, 870-875.

Zhu, H.; Du, M.; Fox, l.; and Zhu, M.J. (2016): bactericidal effects of cinnamon cassia oil against bovine mastitis bacterial pathogens. Food control, 66: 291-299.

\section{التوصيف الثكلي والجيني للسودوموناس ايروجينوزا المعزولة من الكُلى المصابة في بدارى التسمين \\ اسداعيل عبل الحفيظ رضوان ، عبير احدد السبي شحاته ، شبياء حسن عبل الوهاب محمود}

E-mail: tota.toto2021@yahoo.com Assiut University web-site: www.aun.edu.eg

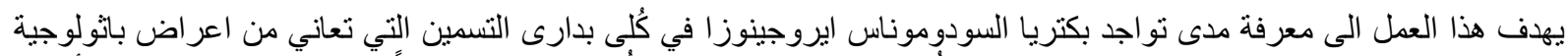

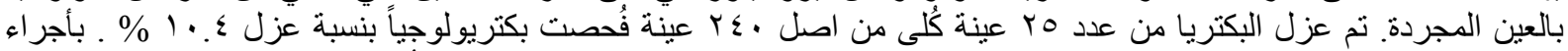

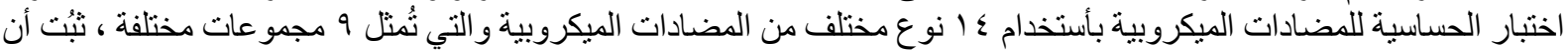

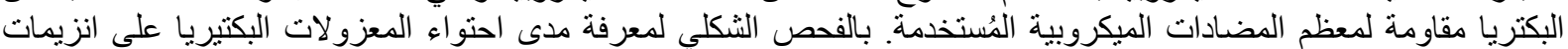

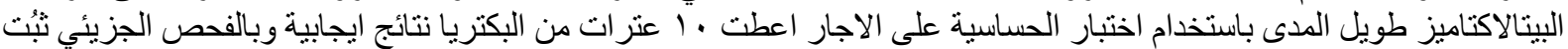

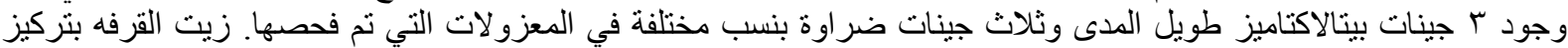

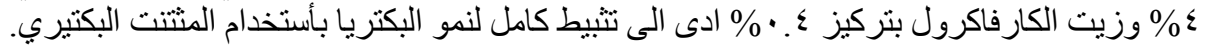

